\title{
Phase II MS4 challenges: moving toward effective stormwater management for small municipalities
}

\author{
Leslie Rieck ${ }^{1}$ (D) Craig Carson $^{2} \cdot$ Robert J. Hawley $^{3} \cdot$ Madison Heller $^{1} \cdot$ Mike Paul $^{4} \cdot$ Mateo Scoggins $^{5}$. \\ Mel Zimmerman ${ }^{1} \cdot$ Robert F. Smith ${ }^{1}$
}

Accepted: 14 October 2021 / Published online: 26 October 2021

(c) The Author(s) 2021

\begin{abstract}
Federal regulations for municipal separate storm sewer systems (MS4s) in the United States have been in place since 1990 as part of the Nation Pollutant Discharge Elimination System (NPDES), aiming to reduce sediment and pollutant loads originating from urban areas. However, small-municipality (Phase II) MS4s frequently grapple with several challenges, resulting in a lack of stakeholder buy-in and actionable stormwater management plans. We identify five common challenges concerning MS4 requirements based on literature review, professional experience, and feedback solicited from stakeholders, municipal managers, and fellow professionals and offer real-world examples of efficient, effective MS4 frameworks and/or solutions. The five challenges are summarized as beliefs that: (1) agricultural land use is the largest pollutant contributor and the root cause of pollution problems; (2) stormwater management only benefits downstream communities; (3) large, expensive projects are required to comply with regulations; (4) maintenance, monitoring, and inspection of best management practices (BMPs) is overwhelmingly complex and expensive; and (5) a lack of direct funding makes complying with regulations an impossible task. These challenges are universal in nature for Phase II MS4 permittees and can create real barriers for effective stormwater management. However, we found many examples of methods or techniques to effectively address these five specific challenges, making them well-suited and important for discussion. BMPs can create tangible improvements for surrounding communities (e.g., reduced streambank erosion and flooding), and improved understanding of the structure and options within the MS4 program will help small municipalities make informed choices about management plans.
\end{abstract}

Keywords Phase II MS4 · Urban stormwater $\cdot$ Best management practice $\cdot$ Municipality $\cdot$ Stakeholders

\section{Introduction}

Urbanization is accelerating globally (United Nations Department of Economic and Social Affairs 2019) through a process that transforms natural land cover into a built landscape dominated by impervious surfaces drained largely by grey infrastructure (e.g., stormwater pipes) and straightened, hardened stream channels (Booth 1991; Alberti et al. 2007; Burcher et al. 2007; Napieralski and Carvalhaes 2016). Urban

Leslie Rieck

rieck@lycoming.edu

Lycoming College, Williamsport, PA 17701, USA

2 McCormick Taylor, Inc, Baltimore, MD 21202, USA

3 Sustainable Streams, Louisville, KY 40205, USA

4 Tetra Tech, Inc, Research Triangle Park, NC 27709, USA

5 City of Austin, Austin, TX, USA landscapes possess a unique hydrologic regime characterized by increased a) severity and frequency of floods (Paul and Meyer 2001; Wenger et al. 2009), b) erosion (Arnold and Gibbons 1996; Paul and Meyer 2001; Pizzuto et al. 2000), c) physical disturbance (Fitzpatrick and Peppler 2010; Vietz et al. 2014; Hawley et al. 2016), and d) concentrations of pollutants in runoff reaching stream channels (Carle et al. 2005; Hobbie et al. 2017). Urban-induced physiochemical alterations to streams typically result in low diversity of invertebrate and fish assemblages (Paul and Meyer 2001; Meyer et al. 2005), altered nutrient cycling (Alberti 2005; O'Driscoll et al. 2010), decreased connectivity to the surrounding terrestrial landscape (Kautza and Sullivan 2015; Alberts and Sullivan 2016), and simplified food webs (Eitzmann and Paukert 2010; Kautza and Sullivan 2016). Stormwater flow paths through highly connected piped systems to stream channels cause a suite of physical, chemical, and ecological changes to urban streams (i.e., the "urban stream syndrome"; Walsh et al. 
2005). Historically, urban stormwater management focused on quickly diverting water into drainage channels to preserve infrastructure (Wohl and Merritts 2007; Chini et al. 2017), but contemporary approaches focus on stormwater quantity and quality to preserve ecological integrity of surface water ecosystems, moving toward a "water sensitive city" that works to retain and/or detain stormwater and filter nutrients, pollutants, and pathogens from as much stormwater as possible on-site before allowing it to return to waterways (Chini et al. 2017; McKenzie 2021).

The landmark ruling in Natural Resources Defense Council v. Costle (NRDC v. Costle 1977) required the U.S. Environmental Protection Agency to regulate stormwater discharges under the National Pollution Discharge Elimination System (NPDES; National Research Council (NRC) 2009). These regulations apply to municipal separate storm sewer systems (MS4s; National Research Council (NRC) 2009). MS4s are stormwater conveyances separate from sanitary sewer systems that collect surface runoff (e.g., from streets via inlets) and deliver it to discrete points where it discharges into water bodies, often streams and rivers (i.e., outflows; United States Environmental Protection Agency (USEPA) 2010). Enforceable rules were implemented for large and medium cities ( $>100,000$ residents according to U.S. Census Bureau population statistics) for Phase I of the Stormwater Permit Rules in 1990 (National Research Council (NRC) 2009; United States Environmental Protection Agency (USEPA) 2010). Phase II Rules added the remaining 'small' urbanized areas $(<100,000$ residents as defined by United States Census Bureau 2020; United States Environmental Protection Agency (USEPA) 2005) to the scope of the permitting requirements with rules to classify which small MS4s were 'regulated' (United States Environmental Protection Agency (USEPA) 2012). Phase II rules are controversial since small municipalities requiring permits lack the resources of large cities to interpret and comply with MS4 regulations (Eisen 1995; Keeley et al. 2013; Brown 2018) and often encounter confusion or difficulties in complying with regulations (Fedorchak et al. 2017).
Permits for small MS4s aim to reduce pollutant discharges to the maximum extent practicable (MEP) via implementation of approved best management practices (BMPs) and six minimum control measures (MCMs; United States Environmental Protection Agency (USEPA) 2005). BMPs are structures or other landscape alterations that will detain, infiltrate, treat, or otherwise improve the quality and quantity of stormwater discharged to a waterway. Numerous options exist for BMPs (Table 1) such as detention ponds, bio swales, or green roofs (United States Environmental Protection Agency (USEPA) 2005). The six MCMs are: (1) public education and outreach; (2) public participation/ involvement; (3) illicit discharge detection and elimination; (4) construction site runoff control; (5) post-construction runoff control; and (6) pollution prevention/good housekeeping (Table 2; United States Environmental Protection Agency (USEPA) 2005).

While the implementation of BMPs and MCMs to comply with regulations might appear straightforward, smallmunicipality MS4 permittees frequently grapple with several common challenges faced by government and community stakeholders that result in a lack of actionable stormwater management plans (Fedorchak et al. 2017; Kim and Li 2017). The central challenge is regulating a diffuse, nonpoint source of pollution (i.e., stormwater) using local authority, with little control over large portions of the stormwater source (i.e., private properties), and limited funding to implement actions (Backhaus et al. 2012; Dhakal and Chevalier 2016; Subramanian 2016). A complicating factor (particularly for funding) is that stormwater management is not typically recognized by community members as a utility service (e.g., drinking water management or waste management), which residents generally accept require taxes or fees for service (National Research Council (NRC) 2009; Dhakal and Chevalier 2016). Maintaining, inspecting, and monitoring BMPs is a small but annual cost compared to the large, infrequent costs usually associated with grey infrastructure projects (Vineyard et al. 2015; Chini et al. 2017; Miller and Montalto 2019; William et al. 2020), causing further challenges to Phase II MS4 permittees that may lack manpower

Table 1 Common structural best management practices (BMPs), examples, and operational capabilities (see Eriksson et al. 2007; Collins et al. 2010; Hilliges et al. 2013; Liu et al. 2014; Zhang et al. 2021; Abdollahanian et al. 2018 for more information)

\begin{tabular}{|c|c|c|}
\hline BMP Group & Example(s) & Operational capabilities \\
\hline Bioretention & $\begin{array}{l}\text { Bioswales } \\
\text { Rain gardens }\end{array}$ & $\begin{array}{l}\text { Some infiltration, peak discharge mitigation, TSS filtration/settling, } \\
\text { varying vegetation nutrient uptake }\end{array}$ \\
\hline Infiltration systems & $\begin{array}{l}\text { Soakaways } \\
\text { Infiltration benches and basins }\end{array}$ & Infiltration, TSS filtration \\
\hline Storage facilities & $\begin{array}{l}\text { Retention ponds } \\
\text { Constructed wetlands } \\
\text { Extended detention basins }\end{array}$ & $\begin{array}{l}\text { Peak discharge mitigation, TSS deposition, vegetation nutrient uptake } \\
\text { in constructed wetlands }\end{array}$ \\
\hline Alternative road structures & Porous pavements & Infiltration, some TSS filtration, some pathogen and nutrient filtration \\
\hline
\end{tabular}


Table 2 Descriptions of the six minimum control measures (MCMs) required by municipal separate storm sewer (MS4) permits and examples of each

\begin{tabular}{|c|c|c|c|}
\hline & Minimum Control Measure & Description & Example(s) \\
\hline 1 & Public education and outreach & $\begin{array}{l}\text { Educating citizens about the impacts of } \\
\text { urban stormwater runoff }\end{array}$ & Posting signs encouraging pet waste pick-up \\
\hline 2 & Public participation and involvement & $\begin{array}{l}\text { Including citizen stakeholders in stormwater } \\
\text { management decision-making processes }\end{array}$ & $\begin{array}{l}\text { Citizen advisory panels, public comment } \\
\text { periods }\end{array}$ \\
\hline 3 & $\begin{array}{l}\text { Illicit Discharge Detection and Elimination } \\
\text { (IDDE) }\end{array}$ & $\begin{array}{l}\text { Identifying illegal discharge sources and } \\
\text { ensuring citizens are properly disposing } \\
\text { of waste }\end{array}$ & Dry-weather inspections of outfalls \\
\hline 4 & Construction site runoff control & $\begin{array}{l}\text { Requiring erosion mitigation programs in } \\
\text { construction requirements }\end{array}$ & $\begin{array}{l}\text { Adding to existing construction regulations } \\
\text { (e.g., silt fences, temporary ponds)) }\end{array}$ \\
\hline 5 & Post-construction runoff control & $\begin{array}{l}\text { Requiring preservation of or creation of } \\
\text { sedimentation- and pollutant-mitigating } \\
\text { structures within newly developed or } \\
\text { redeveloped land }\end{array}$ & $\begin{array}{l}\text { Adding to ordinances and conducting as-built } \\
\text { inspections, O\&M inspections (e.g., retention } \\
\text { ponds, constructed wetlands) }\end{array}$ \\
\hline 6 & Pollution prevention and good housekeeping & $\begin{array}{l}\text { Preventing or reducing pollutant runoff } \\
\text { resulting from municipal activities }\end{array}$ & $\begin{array}{l}\text { Street sweeping, evaluating road salt and } \\
\text { other chemical use }\end{array}$ \\
\hline
\end{tabular}

in maintenance departments and/or employees dedicated to work on urban stormwater programs.

Identifying and describing challenges in satisfying MS4 permit requirements can provide clarity and guidance for municipalities to move past smaller challenges to address the central challenge outlined above. We identified five key challenges to implementing an effective stormwater management program as beliefs that: (1) pollution contributed from urban stormwater is minor compared to agricultural sources and is unfairly targeted by regulatory agencies; (2) only downstream communities will benefit from local actions; (3) effective stormwater management requires large, expensive projects; (4) maintenance, monitoring, and inspection of stormwater management projects is overwhelmingly costly and complicated; and (5) a lack of direct funding is insurmountable and justifies non-compliance (i.e., the "unfunded mandate" argument; Fig. 1). These five challenges are not meant to be an exhaustive list but were identified as part of a candidate set of challenges through literature searches, then selected for further investigation based on their repeated mention during discussions with stakeholders, fellow professionals, and municipal agencies (see Acknowledgements for a short list of those with whom we discussed MS4 issues and Appendix 1 for a list of meetings at which this work was presented in preliminary form to solicit feedback). These five specific challenges are encountered by a wide variety of Phase II MS4 permittees and address confusion regarding MS4-related policies and implementation rather than the central challenge regarding stormwater regulation (discussed above). Excluded challenges addressed regionspecific challenges (e.g., those applicable only in arid climates), infrastructure-specific challenges (e.g., combined sewer systems, technical details of BMP installation or performance), and natural disaster/climate change-related concerns (e.g., increased coastal flooding; discussed in the context of stormwater in Harris 2018). These excluded concerns are better addressed as separate publications due to their highly specific or technical nature. The objectives of this paper are to use a synthesis of relevant literature, the authors' collective professional experiences researching and managing urban stormwater projects, and feedback gathered from discussions with other stormwater professionals during individual meetings and professional conferences to: (1) summarize and describe the complexities of five beliefs posing challenges to designing and implementing MS4 NPDES permit requirements and (2) offer several real-world examples of effective, efficient MS4 management methods to help overcome several of these common misunderstandings or challenges. This work represents two levels of strategy: 1) experiential knowledge development by working as partners with local governments throughout the country (e.g., through consulting or outreach activities; Murphy et al. 2021); and 2) empirically-based review of ecological and socio-political knowledge to address interdisciplinary barriers. These two strategic components interact with knowledge of the regulatory framework that a) constrains possible actions for restorations and $b$ ) influences the socio-political interactions. Here, we demonstrate how a strategy of developing learned experiences working within policy-based restoration actions can translate into non-traditional knowledge bases (i.e., debunked 'misunderstandings' accompanied by empirically-based rationale) can support restoration action. We expect that this research will help bridge the knowledge divide between academia and local government and consultant entities identified by Murphy et al. (2021). Complex interactions among scientists, practitioners, 


\section{Challenges/Beliefs Solutions/Truths}

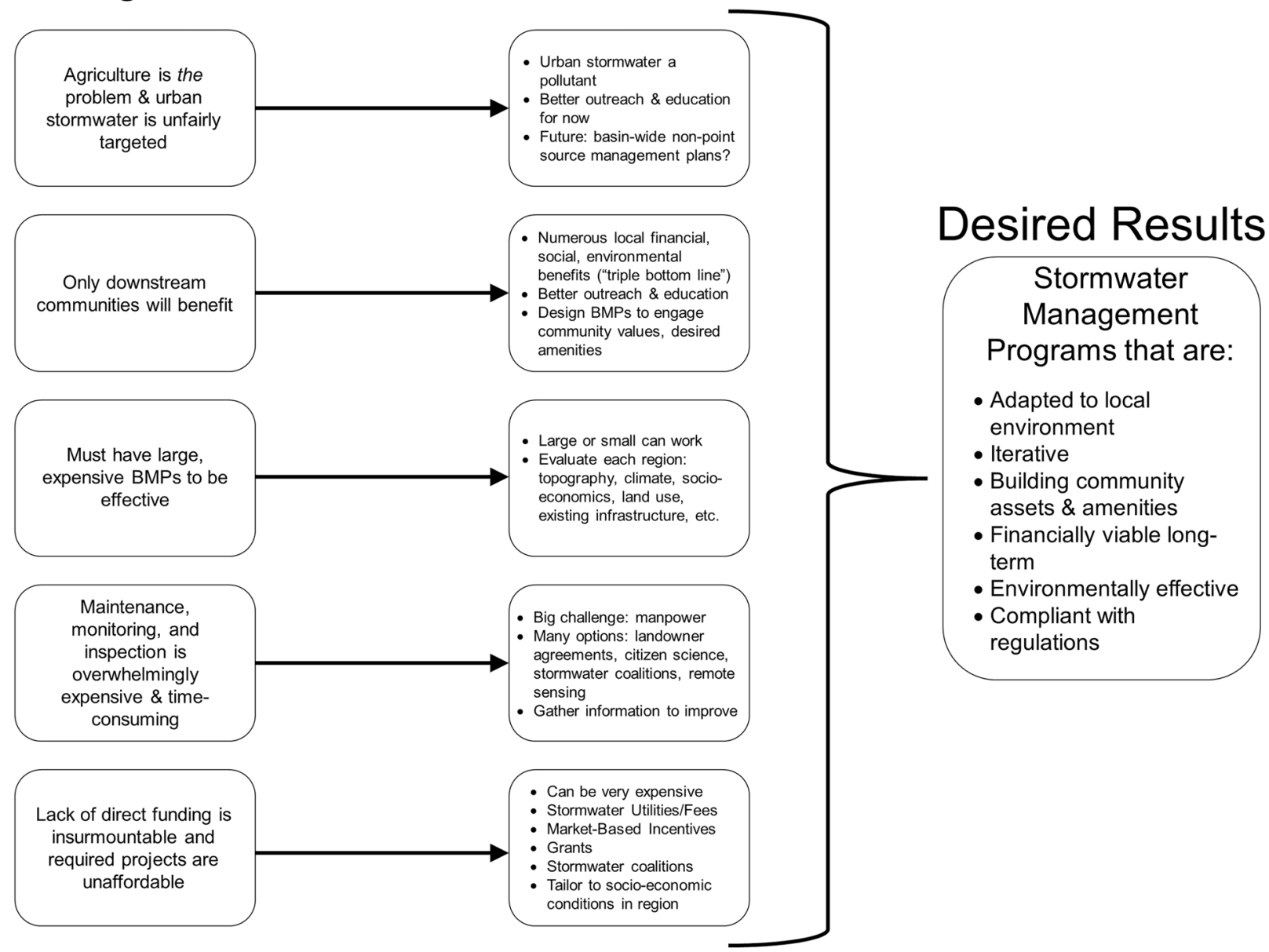

Fig. 1 Five general challenges encountered by Phase II MS4 permittees that can limit the ability to develop programs to comply with MS4 regulations. Better understanding of these challenges and effective solutions to them can allow municipalities and local government

managers, politicians, and the community can substantially influence project trajectories and success and can create barriers to project implementation. Thus, this work aims to clarify ecological knowledge for community entities tasked with implementing regulatory action while simultaneously presenting some common beliefs held and challenges encountered by these community entities to aid the academic community in understanding the perspectives of policymakers and consultants. We posit that municipalities and local governments can most effectively address MS4 permit compliance by helping stakeholders move past perceived policy- and implementation-related challenges and confusion to instead focus on more foundational challenges related to the task of regulating a diffuse, non-point pollution source of pollution originating from largely private property within the context of a regulatory system that treats it as a point source (Fig. 1). opportunities to better focus on more fundamental barriers to attaining regulatory compliance, resulting in the creation of effective, efficient stormwater management plans

\section{The 5 common challenges in small-municipality MS4 programs}

\section{Urban stormwater is a minor pollution source compared to agricultural sources and is unfairly targeted by regulatory agencies}

Agriculture is a large contributor of nitrogen, phosphorus, and sediment pollution (Carpenter et al. 1998; Bernot et al. 2006). Agricultural runoff and irrigation return flow is generally exempt from most or all federal water quality regulations (Schroeder 2015). Federal- (see Natural Resources Conservation Service (NRCS) 2020a) and state-level organizations frequently encourage voluntary actions to manage agricultural stormwater given exemptions to certain regulatory requirements (e.g., Natural Resources Conservation Service (NRCS) 2020b; Pennsylvania Department of 
Environmental Protection 2021a). Concentrated animal feeding operations (CAFOs), however, are regulated by NPDES regulations as point sources of pollution (Schroer 2020). Regulatory exemptions can encourage conflict between upstream agricultural landowners who see urban land use as the main problem and downstream urban communities that argue mitigation should be the responsibility of upstream farm communities that introduced the pollution, enhanced by the complicated situation wherein some agricultural operations (e.g., CAFOs) and any suburban or urban community serviced by storm sewers are covered by more stringent regulatory system as "point sources" while the bulk of agricultural land remains only voluntarily addressed (Eisen 1995; Drevno 2018; Schroer 2020).

Agricultural runoff can contribute to pollutant loads, but urban stormwater introduces ecologically relevant quantities of many target pollutants (United States Environmental Protection Agency (USEPA) 2010; Loperfido et al. 2014) including nutrients ( $\mathrm{N}$ and $\mathrm{P}$ ), heavy metals, herbicides, personal care products, pharmaceuticals, and several plasticizers and common industrial chemicals (Eriksson et al. 2007; Aryal et al. 2010). Urban stormwater is an important pollutant source (Novotny et al. 2010; Zhang et al. 2021), with pollutants commonly originating from soils, chemicals, and other matter rinsing into traditional (gray) stormwater infrastructure, which is piped efficiently to receiving water bodies (United States Environmental Protection Agency (USEPA) 2020). As an example of a watershed impacted by multiple urban centers, urban stormwater contributes $16 \%, 8 \%$, and $15 \%$ of the total sediment, $\mathrm{N}$, and $\mathrm{P}$ loads to the Chesapeake Bay respectively, which are biologically relevant amounts and much higher than expected given that urban areas (as defined by the census) comprise about $8.8 \%$ of the Chesapeake Bay's drainage area (United States Environmental Protection Agency (USEPA) 2010; Loperfido et al. 2014; United States Census Bureau 2019). In California, urban land use and construction are responsible for the impairment of more surface area of lakes than agricultural land use and around $60 \%$ the mileage of streams and rivers as agricultural land use (Drevno 2018). Furthermore, urban landscapes tend to have more erosive flow regimes than their rural counterparts (e.g., erosion rates $\sim 10 \times$ higher; Hawley et al. 2020), and streambank erosion is often a dominant source of sediment pollution in urban streams (Simon and Klimetz 2008). While the sources and forms of pollutants differ between urban and agricultural land uses (Zhang et al. 2021), urban stormwater is a source of pollution in need of attention, potentially through watershed- or region-wide regulations that manage water pollution from all sources holistically to meaningfully abate water pollution (Drevno 2018; McKenzie 2021). In the interim, seeking out BMPs that effectively treat urban stormwater and emphasizing the impact of urban stormwater pollutants and the additional benefits of stormwater BMPs during public education and outreach events is imperative to gaining public trust and cooperation in creating effective stormwater management plans (Coleman et al. 2018; Miller and Montalto 2019; Darnthamrongkul and Mozingo 2020).

\section{Stormwater management actions only benefit those living downstream}

A commonly publicized benefit of effective stormwater management is improved environmental conditions to downstream communities often referencing estuaries, beaches, and other coastal ecosystems (e.g., see Chesapeake Bay Foundation 2019). Downstream benefits are likely outcomes of improved stormwater management (Roy et al. 2008; National Research Council (NRC) 2009), but multiple direct benefits to local streams and the surrounding communities can also occur following urban stormwater improvement projects. Maintaining and protecting local water supply, mitigating flooding (Fletcher et al. 2013), resistance to climate change (Harris 2018), and increased human well-being are potential co-benefits of "water-sensitive" urban stormwater designs (Walsh et al. 2016). Reduced property loss and infrastructure impacts from excessive streambank erosion (Hawley et al. 2020), increased property values (Ward et al. 2008; Odefey et al. 2012; Mazzotta et al. 2014), and the ability to use stormwater as an asset through groundwater recharge or rainwater reuse (Odefey et al. 2012; Meng and Hsu 2019) are also tangible benefits to local residents (e.g., in Los Angeles County, USA, stormwater detention is designed specifically for the purpose of groundwater recharge; Porse and Pincetl 2019). The potential to re-use stormwater runoff has appeal to local communities especially in arid areas. Stormwater management can be an important part of a city's water resources portfolio for future human purposes given appropriate, risk-based regulations (Goonetilleke et al. 2005; Birchai and Ashbolt 2017; Austin Water 2018; US Water Alliance 2020).

Flooding is also a problem for urban communities (Odefey et al. 2012; Center for Disaster Resilience 2018), but flood risk and other negative impacts of urban stormwater in poor neighborhoods are often disproportionately high globally due to housing and planning practices that restrict impoverished people to living in less "desirable" areas, including floodplains (Parkinson 2003; William et al. 2020). Thus, urban flood mitigation can address social inequities. Climate change will likely exacerbate urban flooding, and green infrastructure (an acceptable BMP) has the potential to mitigate increased stormwater runoff resulting from future climate more effectively than existing gray infrastructure (Dong et al. 2017; Harris 2018; Giese et al. 2019; Ramsey et al. 2019).

Stormwater infrastructure across the US is rapidly aging past its intended lifespan (Keeley et al. 2013; Hoover and Hopton 2019; Vineyard et al. 2015; Meng and Hsu 2019). In a stark example, Hoard et al. (2020) were investigating 
the hydrology of an abandoned residential area in Detroit in anticipation of BMP installation when they detailed what they described as "urban karst": a patchwork of crumbling drainage pipes, leaking water pipes, and failing building foundations, leading to complex, sometimes horizontal, stormwater flow combined with flow from other sources (e.g., leaking water pipes). Direct benefits to local communities when severely degraded infrastructure is discovered and repaired are obvious, but stress on functional infrastructure is potentially reduced when stormwater is efficiently captured and treated by new BMPs or stormwater retrofits before entering drainage systems. Actions to maintain and extend the life of stormwater infrastructure can also reduce costs to municipalities and residents. Thus, integrating green infrastructure, retrofits, and maintenance of functioning gray infrastructure as a part of urban renewal initiatives (e.g., Hawley et al. 2015) can improve stormwater quantity and quality while potentially lessening the financial burden for municipal residents (Montalto et al. 2007; Jarden et al. 2016; Manocha and Babovic 2017).

Expanding the capacity of stormwater systems by adding green infrastructure as part of system updates and upgrades can also have important benefits to ecosystem structure and function such as infiltration (baseflow), mitigation of urban heat island effects, and increased biodiversity (Milwaukee Metropolitan Sewerage District (MMSD) 2018), but local communities may not easily recognize the value of ecosystem services resulting from these changes (Elmqvist et al. 2015; Coleman et al. 2018; Miller and Montalto 2019). Meeting stakeholder aesthetic and cultural preferences for BMPs and urban landscape design as part of programs to maintain diverse ecosystem services can lead local communities to see stormwater systems as providing tangible local benefits (Miller and Montalto 2019; Darnthamrongkul and Mozingo 2020; William et al. 2020). Achieving this benefit requires managers to include communities in decision-making processes and can help create resilient and effective programs with local social and ecological co-benefits (BenDor et al. 2018; Hoover and Hopton 2019; Miller and Montalto 2019). Increased property values resulting from effective BMP implementation and landscape design (including green infrastructure) can benefit property owners and municipalities through increased tax revenue (Ward et al. 2008; Odefey et al. 2012; Mazzotta et al. 2014).

Homes in low-impact development (LID; a form of development that seeks to mimic the natural hydrology of the site) neighborhoods with large quantities of greenspace and redesigned streets improved stormwater drainage while increasing home prices by $3.5-5 \%$ compared to similar homes in nonLID neighborhoods (Ward et al. 2008; Mazzotta et al. 2014). Mazzotta et al. (2014) found that property value increases from the benefits of open green space associated with LID were site-specific and depended on distance from LID features. Green stormwater infrastructure can address poor air quality, increase urban green space (with corresponding increases in residents' physical and mental health), and potentially decrease crime while addressing some societal inequity (Ashley et al. 2018; Miller and Montalto 2019; William et al. 2020). Personal safety such as safe wading access (even in small streams through city parks) is an additional service that residents are likely to recognize as a tangible benefit (Hawley 2018). The benefits of green stormwater infrastructure are sometimes said to satisfy a "triple bottom line," providing simultaneous social, environmental, and financial improvements (Taylor and Fletcher 2006; Neukrug and Camp 2009; Vineyard et al. 2015).

Ensuring public education and outreach materials focus on stakeholder values and preferences will improve local buy-in and create long-term support for urban stormwater planning and management programs (Coleman et al. 2018; Miller and Montalto 2019; McKenzie 2021). Local benefits of improved water quality may be overlooked when public outreach is only centered on an iconic downstream ecosystem (e.g., the Chesapeake Bay). Existence value (i.e., value based on continued existence even if not used; Attfield 1998) of distant ecosystems will differ among people, and improved educational approaches and understanding of socio-cultural preferences of stakeholders in small municipalities will improve efforts to develop and maintain community buy-in.

\section{Effective stormwater management requires large, expensive projects}

Small municipalities typically have a mix of stormwater infrastructure that reflects design standards in place at the time of development. Stormwater is commonly managed as a nuisance or threat to properties and safety and secondarily as a threat to water quality. Ditches, pipes, swales, and large dry or wet detention basins, when installed by developers during construction, are relatively low cost and dependable approaches for reducing flooding issues that impact people and property (Collins et al. 2010; Brown 2013; Cettner et al. 2013; Hale 2016). However, these traditional systems do not always adequately address the rate of stormwater flow and quality, leading to continued problems with erosion and water pollution (Collins et al. 2010; Cappiella et al. 2012). Beyond limitations for original construction, the cost and logistical issues (e.g., lack of available public land) required to retrofit stormwater management projects ranging from detention ponds to complete re-engineering of stormwater drainage system (Cappiella et al. 2012) may be out of reach for municipalities where there are no existing BMPs or they don't adequately treat/attenuate stormwater runoff to sufficiently protect receiving streams from pollutants and excess erosion. A highly engineered redesigned storm sewer system that includes underground storage may be an effective 
short-term solution, but its large expense and potentially limited capacity for additional development/redevelopment may make it less viable than small source control projects that do not require re-engineering the existing system (Barbosa et al. 2012; Vineyard et al. 2015).

Stormwater standards and preferred BMPs have evolved over the years (e.g., Roy et al. 2008; Chini et al. 2017). Development (or redevelopment) methodologies that retain as much rainfall as possible on individual parcels may result in hydrologic regimes that approach natural conditions and are effective at reducing contaminant loads. Low impact development (i.e., green stormwater infrastructure) seeks to best approximate pre-development hydrological conditions, which, if achieved, can effectively address both water quantity and quality (Cappiella et al. 2012; Odefey et al. 2012). Small, low-cost, widely-distributed, parcel scale projects (i.e., "source-control") such as vegetated swales, green streets, porous or permeable pavement, can provide stormwater control equivalent to or more effective than large centralized projects when properly sized and located (Cook 2007; Collins et al. 2010; Vineyard et al. 2015; Montalto et al. 2007; Dong et al. 2017); though see Roy et al. 2014; Fanelli et al. 2017; Hopkins et al. 2020 for potential limitations). Small-scale projects may be the better alternatives to large projects that must overcome limited space and uncooperative landowners (Backhaus et al. 2012; Malinowski et al. 2018; Woznicki et al. 2018), particularly in areas with no opportunity to retrofit pre-existing stormwater management structures. Numerous small-scale projects can save money on future needs for infrastructure spending (e.g., drinking water treatment facilities; Cappiella et al. 2012; Odefey et al. 2012). Eriksson et al. (2007), defined four main groups of BMPs that can be implemented over broad areas: (1) filter strips or swales; (2) infiltration systems (e.g., infiltration basins or trenches); (3) storage facilities (e.g., retention ponds, treatment wetlands; and (4) alternative roads (e.g., porous pavements; Table 1).

Smaller projects are not the most effective or affordable choice for every situation. Small projects may be ineffective in heavily urbanized watersheds (Fanelli et al. 2017), and a single large project (or a modification of an existing traditional SCM) may be cost-effective using modern modifications when land is available (Smith et al. 2016; Hawley et al. 2020). Decentralized BMPs with equal performance to traditional, centralized systems (e.g., Mayer et al. 2012; Roy et al. 2014; Hopkins et al. 2020) may be more expensive (Hawley et al. 2017) or are equally poor at attaining predevelopment hydrology (Jefferson et al. 2017). Acknowledging the context dependency of small BMP effectiveness can inform management and lead to mixed approaches such as being used as part of a treatment train (Sparkman et al. 2017; Read et al. 2019) and tailored approaches for catchment characteristics and regional climate (Askarizadeh et al. 2015; Zhang et al. 2021).

\section{Maintenance, monitoring, and inspection requirements are overwhelmingly expensive}

Funding ongoing maintenance, monitoring, and inspection programs is a challenge for many MS4 permittees (William et al. 2020), and this challenge is likely greater in Phase II municipalities that often have smaller municipal maintenance departments and may not have a department or employee solely tasked with managing stormwater. This lack of continuous attention can be problematic: a lack of monitoring and a poorly defined stormwater management program can increase a municipality's likelihood of heavy fines resulting from an audit (Tetra Tech Inc. 2006; National Association of Clean Water Agencies 2018).

Tetra Tech Inc. (2006) found several common deficiencies in their assessment of $36 \mathrm{MS} 4$ programs that included inadequate BMPs for publicly owned facilities, lack of written stormwater pollution prevention plans, lack of monitoring programs or demonstrated effectiveness, or a lack of inspections of required sites (e.g., construction sites and municipal facilities). Mirroring these findings, frequent areas of non-compliance at a national scale are typically associated with MCMs 3-6 (Table 2), including a lack of an illicit discharge detection and elimination program (or an insufficient one), a lack of inspection at construction sites, no regulatory mechanisms through which to monitor and regulate post-construction runoff BMPs' maintenance and function, or poor housekeeping procedures at municipal facilities (e.g., uncovered dumpsters, salt sheds, paint drums, etc.; National Association of Clean Water Agencies 2018). These requirements necessitate a consistent investment of time and money compared to the single (though larger) investment necessary for grey infrastructure (Miller and Montalto 2019). However, alternate options exist for monitoring, maintenance, and inspection, and many green infrastructure BMP options, such as rain gardens, cost less to maintain and operate over time than the corresponding grey infrastructure (McKenzie 2021).

Promising options for low-cost monitoring programs may lie in remote sensing (Matejicev et al. 2003; Heasley et al. 2020), citizen science (Cartwright et al. 2015; Shupe 2017; Kielstra et al. 2019), inter-departmental collaboration within municipal governments, or collaboration with higher educational institutions. Using technology and stakeholder/citizen programs to gather information can lower costs and improve efficiency of data collection programs. (Ramsey et al. 2019) note that municipal staff in San Juan, Puerto Rico do not currently use citizen calls to monitor urban flooding but would be willing to if a phone application was available that would include time-stamped photos of issues, a solution that may prove useful for both flooding and illicit discharge monitoring.

Citizen participation can aid in maintenance and also encourage stakeholder buy-in, as was shown to be the case with volunteers who were trained to aid in maintenance of 
bioswales in New York City, who were then more likely to support additional green stormwater infrastructure and identify its benefits (Miller and Montalto 2019). Landowners can also be important partners in maintenance: rain gardens installed on residential parcels in Cincinnati, Ohio were maintained by the homeowners, allowing the municipality to conduct occasional inspections without having to provide continual maintenance (Vineyard et al. 2015). Partnerships between the community and the municipality can greatly aid in creating an iterative stormwater management program in which maintenance, monitoring, and inspection are clearly defined in the original stormwater management plan, with private landowners receiving adequate incentive and support to install and maintain BMPs on their property and municipalities forming maintenance and inspection teams with clearly defined goals (Chini et al. 2017).

Information gained from maintenance, monitoring, and inspection programs can be tremendously valuable as cities seek to improve their programs and share information with other municipalities to improve region- and nation-wide stormwater quality (Chini et al. 2017). Monitoring may also provide valuable information in the case of an audit, significantly reducing exposure and risk with state and federal agencies (Tetra Tech Inc. 2006; National Association of Clean Water Agencies 2018).

While the maintenance, monitoring, and inspection of BMPs can be intimidating and requires an adjustment in expected expenditures, addressing public education, outreach, and participation MCMs may aid small municipalities in identifying effective solutions within the community.

\section{Regulations lack direct funding}

A common argument is that the Phase II MS4 permitting regulations lack federal funding for implementation, and as a result, municipalities (and local communities) are unfairly burdened with meeting permitting requirements through stormwater management programs (Allerhand et al. 2012). Of 7,500 MS4 permittees, only 1,500-2,000 have dedicated funding of any kind and more than half of surveyed small municipalities cite the need for additional financial resources to establish effective stormwater programs (Brown 2018). Expanded regulations included in a 2016 revision of the MS4 program are estimated to cost municipalities a total of $\$ 454,000$-\$1.3 million per municipality in addition to costs attributed to greater inter-departmental collaboration (Civian 2018).

Community and government stakeholders and even municipalities sometimes argue that noncompliance is justified by citing the "Unfunded Mandates Reform Act of 1995" under which states and other localities may not have to comply with federal regulations (such as the MS4 NPDES program) that lack federal funding (Eisen 1995; Irvine et al.
2011). An additional justification for noncompliance is the argument that permitting requirements may "bankrupt" the local government, but we found no examples of small cities or municipalities going bankrupt by complying with stormwater regulations (however, see Levin et al. 2011; Walsh 2012; Pries 2019 as several examples of wastewater infrastructure bankrupting towns). Schroer (2020) uses Lebanon, Pennsylvania as an example of a Phase II MS4 that is experiencing financial hardship due to recent regulatory changes, and though Lebanon is not bankrupt, it is struggling to afford a program it estimates may cost $\$ 1.4$ million annually. Creation of effective stormwater programs is legitimately hampered by a lack of direct funding, and the ability to rely solely on existing taxes and fees to fund programs is uncommon. Thus, innovative funding approaches are necessary (National Research Council (NRC) 2009), which may include the utilization of grants, new taxes, creation of stormwater utilities that can charge fees for service, and market-based mechanisms to encourage private landowner implementation of stormwater management practices.

The cost-effectiveness of stormwater utility fees or freemarket mechanisms (e.g., allowance markets, retrofit auctions) may be the most suitable funding mechanisms when direct funds are not available (Barbosa et al. 2012; University of North Carolina School of Government 2020). Creating a utility service akin to services for domestic water and sewer use (or assigning management to an existing utility service) is an option for establishing a stormwater utility fee. Fees based on some measure of per-unit runoff or impervious cover level from parcels can directly fund stormwater management (Eisen 1995; National Research Council (NRC) 2009; Keeley et al. 2013; Kea et al. 2016), though they may not always be the most effective at abating pollution (William et al. 2017). A variety of fee structures have been developed that can be considered by municipalities as they seek to balance ease of calculation, revenue generation, and the equitability of cost to landowners (Fedorchak et al. 2017).

Free-market mechanisms generally work by a) providing an offset to encourage private landowner actions to increase stormwater uptake on their property (e.g., a fee reduction for quantity of runoff diverted and infiltrated) or b) a direct financial incentive to install BMPs on private property (e.g., a reverse auction; Thurston et al. 2003; Barbosa et al. 2012; Brown et al. 2016; Nemes et al. 2016). Fee reductions may be effective in incentivizing BMP installations on private property, but may also exacerbate inequity in certain communities, making the implementation of fees and fee reductions a highly local decision (Fedorchak et al. 2017; William et al. 2017, 2020). Collaboration between small municipalities through the formation of stormwater coalitions may be another option to reduce costs by developing collective training programs, templates for ordinances and 
annual reports, public education materials and programs, and group purchasing or contracts of maintenance and good housekeeping measures (Chaffin et al. 2016; Civian 2018). Grants from various sources can also be a source of external funds, but municipalities may lack the expertise to create a competitive proposal for limited opportunities with high demand (e.g., Pennsylvania Department of Environmental Protection 2021b). Grant management and accounting can also increase cost through administrative duties but could be mitigated through partnerships with local conservation agencies or environmental groups.

Municipalities will benefit most from a funding strategy tailored to their community, given that the above strategies will have differing effectiveness based on highly local socio-political and environmental factors (William et al. 2017, 2020). Approaches should be complementary of other programs/services, be structurally consistent with local regulations, and incorporate regionally appropriate lessons/strategies. Similarly, funding methods are not mutually exclusive. Stormwater fees can be offset by grant writing, and coalitions can combine resources to diversify their collective portfolio of funding options. Coalitions can be complicated to manage and may lead to limited benefits when municipalities in the coalition have different levels of affluence, community support, and capabilities for utilizing different funding methods that limit consensus. Similarly, socio-political interactions at the municipality level can be difficult to manage depending on the leadership structure of the municipality.

\section{Examples of effective, efficient stormwater management programs}

Existing stormwater management programs can illustrate strategies for addressing the challenges discussed above. The real-world examples presented below detail the subtleties of how these challenges result in problems and barriers for managers of urban stormwater systems and describe strategies for overcoming them.

Effective outreach and education programs targeted towards citizen and local government stakeholders can address concerns about upstream agriculture (1) and the lack of local benefits (2). Stakeholders advocating for a focus on upstream agricultural stormwater sources are often interested in focusing efforts on systems with a perceived high return on investment. Agriculture can degrade water quality (Willis and McDowell 1982; Bernot et al. 2006; Schroer 2020), and farms are commonly large parcels with a single owner to negotiate with for project implementation that can support large (see challenge 3 ) and effective projects with measurable benefits. Thus, using limited resources on projects with high achievability and beneficial outcomes (i.e., "low-hanging fruit") makes intuitive sense. The key to overcoming this challenge is, in part, to demonstrate that both agricultural and urban systems contribute in ecologically meaningful ways to poor water quality through stormwater inputs. Outreach alone will not solve this problem, but it can at least set a foundation demonstrating that managing urban stormwater can produce tangible benefits to water quality.

Both challenges 1 and 2 are also influenced by a lack of understanding of the spatial structure of ecological, hydrological, and social processes that link human wellbeing, stormwater, and water quality through management approaches. These concepts are complex and interdisciplinary, and outreach on these topics need to communicate simple and intuitive messages about spatial patterns. Feedbacks resulting from improving downstream water quality to upstream communities are difficult to communicate, which exacerbates the challenge of gaining stakeholder support for using locally derived resources (usually money) to benefit downstream ecosystems. Appealing to a sense of regional community and promoting conservation based on existence value may help but highlighting the tangible local benefits to communities could be most effective and changing stakeholder perceptions even if the overall ecological benefits are small locally and substantial regionally (Coleman et al. 2018; McKenzie 2021). Individuals to target for outreach and education represent diverse positions in the community and demographic groups (Coleman et al. 2018; William et al. 2020), which requires a diverse set of approaches and partners with empirically based knowledge of effective approaches to education (e.g., colleges and universities and associated extension offices). Local perceptions of BMP options, such as green infrastructure, can vary between neighboring municipalities based on socio-cultural, economic, political, and environmental differences (Turner et al. 2016; Miller and Montalto 2019; Shandas et al. 2020). Additionally, MS4 permits give credit to local municipalities for education and outreach activities. Thus, a substantial need exists for a) pedagogy research on effective educational approaches for explaining the intersection of human-generated stormwater, surface water ecosystems, and human wellbeing and $b$ ) the development of transferable and easily deployable educational tools that can be adapted by managers with little experience with instruction or even public speaking.

Challenges regarding project size (3), monitoring/maintenance (4), and funding (5) are intimately tied together and many examples of successful projects explicitly addressed multiple factors simultaneously. Western Michigan University used state and federal grants to directly calculate the required $\mathrm{P}$ load reduction for a TMDL (total maximum daily load reduction requirement), which when combined with stormwater retrofits installed as a component of capital 
improvements projects, resulted in a recalculation that indicated they met their P TMDL requirements ahead of schedule and at low cost (Allerhand et al. 2012).

The Little Stringybark Creek programs, including Storm Tender, successfully used market-based incentives for private homeowner adoption of stormwater management strategies (Nemes et al. 2016). As Nemes et al. (2016) reported, seven rain gardens and 71 water tanks were successfully installed on private residential properties using a reverse auction. An Environmental Benefit Index was used to evaluate the runoff reduction potential of each parcel, and homeowners could submit bids to install stormwater tanks or rain gardens on their property. Administrators then accepted bids to maximize the environmental benefit per unit cost. As stated, this approach can address runoff from private properties that is otherwise difficult to mitigate. Stormwater is not recognized as a pollutant in a way that allows local governments to unilaterally take management action on private land even though the municipality bears the responsibility for management via the permitting system (Brown et al. 2016; Dhakal and Chevalier 2017; National Association of Clean Water Agencies 2018). Thus, creative strategies to encourage collective resident actions to reduce stormwater at the parcel level can lessen the size needed for centralized stormwater solutions. Factors driving homeowner decisions to participate included the perceptions of the technology, the group facilitating the market, understanding of stormwater, and general personal beliefs (Brown et al. 2016), which highlighted the need for effective public education and outreach.

The Shepherd Creek Project in Cincinnati, Ohio, used a reverse auction system to install 83 rain gardens and 176 rain barrels within a single watershed (Mayer et al. 2012). Shuster and Rhea (2013) conducted follow-up monitoring on subcatchment-level runoff volumes following rain barrel and rain garden implementation and found small, yet significant, reductions in storm runoff. No significant ecological improvements occurred over the six to seven years of post-installation monitoring, which suggested that additional treatment was necessary (Roy et al. 2014) but may also reflect the generally poor understanding of ecological response to any restoration activity (Bernhardt et al. 2005; Palmer et al. 2005; Bernhardt and Palmer 2007). Regardless, Life Cycle Cost and Environmental Impact Analysis showed that using rain gardens in this area was financially and environmentally favorable relative to expanding traditional gray infrastructure, particularly with homeowners conducting the few hours of maintenance per year necessary for each rain garden (Vineyard et al. 2015). Grant-funded programs like the Shepherd Creek program are rare and may be out of reach for many small municipalities. This example emphasizes that monitoring may be complicated but can provide valuable information that leads to more effective implementation on future phases/projects.
Coalitions and partnerships can be a valuable tool for addressing all of the challenges. For example, Hamburg (Germany) Wasser collaborated with the State Ministry for Energy and the Environment to start an interdisciplinary task force to address stormwater problems within Hamburg (Bertram et al. 2017). The approach leveraged expertise across agencies to gather information about the stormwater system and the creation of an extensive geographic information database that improved the ecological outcomes and cost effectiveness of the final design, specifically by providing fine-scale data on the location and condition of existing stormwater infrastructure and connected impervious surfaces (Bertram et al. 2017). Leveraging expertise can lead to improved outcomes, but a long-term commitment to project outcomes is required to ensure the partnership is equitable and beneficial to all parties and equally addresses local socio-cultural concerns and broad advancements in stormwater management and science (Prosser et al. 2015).

Another example from the Cincinnati, $\mathrm{OH}$, area has shown that a science-based monitoring and data collection approach combined with the formation of local community partnerships can allow government managers and consultants to leverage existing infrastructure to build effective stormwater management tools (Wooten et al. in prep, Freshwater Science). This holistic approach shows the true utility of moving past the five challenges outlined here to form community-based stormwater management plans that are tightly linked to local environmental conditions and existing infrastructure.

These preceding examples illustrate the importance of community-specific factors when implementing effective stormwater programming. Monitoring needs, funding options, and socio-physical characteristics of any small municipality are unique. We posit that small municipalities require resources through toolkits and partnerships to help find and choose from an appropriate suite of BMPs for their specific situation (e.g., Hawley et al. 2017). Support must combine technical expertise and education and outreach to address complex systems such as how site suitability (physical characteristics, parcel ownership, etc.), location within a watershed, connectivity to other BMPs and existing green spaces all affect the logistics and cost-effectiveness of green infrastructure integration (Malinowski et al. 2018). Opportunities exist for ecologists, engineers, educators, social scientists, and others to develop empirically-based holistic approaches to help manage urban stormwater.

\section{Conclusions}

NPDES Phase II MS4 regulations are intended to create a system for implementing manageable practices for municipalities to comply with federal regulations, but 
criticisms about and confusion surrounding funding, implementation, and environmental effect are legitimate. Many small municipalities lack the resources and expertise to address the complex issues involved in the MS4 program in a manner that aligns with their roles as public servants to local communities. Persistent challenges rooted in financial and logistical concerns hamper municipalities' abilities to comply with regulations by distracting focus from more foundational challenges regarding treatment of stormwater. Demonstrating the ecological relevance of urban stormwater, benefits to local stakeholders, flexibility of project size, benefits of monitoring and maintenance, and surmountable funding barriers can prevent stakeholders from fixating on options for non-compliance and lead to effective management programs. Resources utilized on efforts to avoid compliance will likely lead to additional complications in the future with less resources to address them. Education and outreach are key to informing stakeholders about commonly encountered challenges. Inter-institutional and public-private collaborations may help create coalitions and other external support systems that can assist municipalities with limited capacity for stormwater management seeking to comply with stormwater regulations including the ability to provide in-kind match for project grants through personnel hours from student internships and professional expertise. Permittees may need assistance with understanding permits, interpreting project designs from consultants, and creating education and outreach materials to comply with permit requirements. Partnerships with physical and social science researchers can create new opportunities for active research and teaching about effective stormwater management from a socio-ecological standpoint. Highly motivated and talented personnel within local government can create and manage complex coalitions, but educational institutions need to do more to train individuals for the interdisciplinary nature of managing stormwater cities at the local government level.

MS4 programs are manageable for small municipalities, can be funded in multiple ways, and can result in real, concrete improvements in local communities. The keys to effective programs are dynamic, creative funding mechanisms, horizontal and interdisciplinary collaboration, effective public education, and careful planning, siting, and execution of BMPs. Accomplishing these components is no easy feat but can lead to unexpected benefits (e.g., aesthetic improvements, recreational opportunities, increased property values) for many small cities as part of redevelopment and re-envisioning cities. Stormwater BMPs implemented as part of MS4 programs provide tangible benefits that directly address community priorities through their visibility on the landscape and improvements to local streams and water resources (e.g. reduced stream erosion, cleaner creeks for wading, reduced nuisance flooding, etc.). Making MS4 programs work for small municipalities is essential, and we believe a broad effort on the part of municipal employees, professional consultants, and academics in the social and natural science disciplines to create strategies for dealing with these interdisciplinary problems holds promise for unifying local communities around environmental improvement. This approach is likely to be applicable to a broad suite of environmental issues globally and emphasizes the many ways interdisciplinary knowledge can be obtained, shared, and use to create real-world solutions to environmental problems.

Supplementary information The online version contains supplementary material available at https://doi.org/10.1007/s11252-021-01179-3.

Acknowledgements This research was supported by a Private Higher Education grant from the Arthur Vining Davis Foundations (Grant No. G-1801-18074). We thank the Pennsylvania Department of Environmental Protection for discussions about their experiences with MS4 permitting. We also thank community partners working with the Lycoming College Clean Water Institute on this research and specifically Marcia LeBeau and Wendy Walter from the Williamsport Municipal Water Authority and Bill Burdett from Loyalsock Township. We also thank Rebecca Davis from Lower Allen Township for talking with us about her experiences managing an MS4 program and coalition.

Author contribution L.O. Rieck, R.F. Smith, and M. Zimmerman conceptualized the manuscript, with all authors contributing to research, content, and editing. L.O. Rieck wrote initial drafts and oversaw editing.

Funding This research was supported by the Arthur Vining Davis Foundations Private Higher Education Grant No. G-1801-18074.

\section{Declarations}

Conflicts of interest The authors state no conflicts of interest or competing interests.

Open Access This article is licensed under a Creative Commons Attribution 4.0 International License, which permits use, sharing, adaptation, distribution and reproduction in any medium or format, as long as you give appropriate credit to the original author(s) and the source, provide a link to the Creative Commons licence, and indicate if changes were made. The images or other third party material in this article are included in the article's Creative Commons licence, unless indicated otherwise in a credit line to the material. If material is not included in the article's Creative Commons licence and your intended use is not permitted by statutory regulation or exceeds the permitted use, you will need to obtain permission directly from the copyright holder. To view a copy of this licence, visit http://creativecommons.org/licenses/by/4.0/.

\section{References}

Abdollahanian S, Kazemi H, Rockaway T, Gullapalli V (2018) Stormwater quality benefits of permeable pavement systems with deep aggregate layers. Environments 5(68)

Alberti M (2005) The effects of urban patterns on ecosystem function. Int Reg Sc Rev 28(2):168-192. https://doi.org/10.1177/ 0160017605275160 
Alberti M, Booth D, Hill K, Coburn B, Avolio C, Coe S et al (2007) The impact of urban patterns on aquatic ecosystems: An empirical analysis in Puget lowland sub-basins. Landscape Urban Plan 80(4):345-361. https://doi.org/10.1016/j.landurbplan.2006.08.001

Alberts JM, Sullivan SMP (2016) Factors influencing aquatic-toterrestrial contaminant transport to terrestrial arthropod consumers in a multiuse river system. Environ Pollut 213:53-62. https://doi.org/10.1016/j.envpol.2016.02.003

Allerhand JE, Boyer KB, McCarthy J, Kieser MS (2012) The cost of managing stormwater. J Green Build 7(3):80-91. https://doi. org/10.3992/jgb.7.3.80

Arnold CL, Gibbons CJ (1996) Impervious surface coverage - the emergence of a key environmental indicator. J Am Plann Assoc 62(2):243-258. https://doi.org/10.1080/01944369608975688

Aryal R, Vigneswaran S, Kandasamy J, Naidu R (2010) Urban stormwater quality and treatment. Korean J Chem Eng 27(5):13431359. https://doi.org/10.1007/s11814-010-0387-0

Ashley R, Gersonius B, Digman C, Horton B, Smith B, Shaffer $P$ (2018) Including uncertainty in valuing blue and green infrastructure for stormwater management. Ecosyst Serv 33:237-246

Askarizadeh A, Rippy MA, Fletcher TD, Feldman DL, Peng J, Bowler $P$ et al (2015) From rain tanks to catchments: Use of low-impact development to address hydrologic symptoms of the urban stream syndrome. Environ Sci Technol 49(19):11264-11280. https://doi.org/10.1021/acs.est.5b01635

Attfield R (1998) Existence value and intrinsic value. Ecol Econ 24(23):163-168. https://doi.org/10.1016/s0921-8009(97)00140-7

Austin Water (2018) Water forward integrated resource plan: A water plan for the next 100 years. http://austintexas.gov/sites/default/ files/files/Water/WaterForward/Water_Forward_Plan_Report__A_Water_Plan_for_the_Next_100_Years.pdf. Accessed 13 Sept 2020

Backhaus A, Dam T, Jensen MB (2012) Stormwater management challenges as revealed through a design experiment with professional landscape architects. Urban Water J 9(1):29-43. https://doi.org/ $10.1080 / 1573062 \times .2011 .633613$

Barbosa AE, Fernandes JN, David LM (2012) Key issues for sustainable urban stormwater management. Water Res 46(20):67876798. https://doi.org/10.1016/j.watres.2012.05.029

BenDor TK, Shandas V, Miles B, Belt K, Olander L (2018) Ecosystem services and US stormwater planning: An approach for improving urban stormwater decisions. Environ Sci Policy 88:92-103. https://doi.org/10.1016/j.envsci.2018.06.006

Bernhardt ES, Palmer MA (2007) Restoring streams in an urbanizing world. Freshw Biol 52(4):738-751. https://doi.org/10.1111/j. 1365-2427.2006.01718.x

Bernhardt ES, Palmer MA, Allan JD, Alexander G, Barnas K, Brooks $S$ et al (2005) Ecology - synthesizing US river restoration efforts. Science 308(5722):636-637. https://doi.org/10.1126/science. 1109769

Bernot MJ, Tank JL, Royer TV, David MB (2006) Nutrient uptake in streams draining agricultural catchments of the midwestern United States. Freshw Biol 51(3):499-509. https://doi.org/10.1111/j.13652427.2006.01508.x

Bertram NP, Waldhoff A, Bischoff G, Ziegler J, Meinzinger F, Skambraks AK (2017) Synergistic benefits between stormwater management measures and a new pricing system for stormwater in the City of Hamburg. Water Sci Technol 76(6):1523-1534. https://doi.org/10.2166/wst.2017.337

Birchai F, Ashbolt N (2017) Public health and water quality management in low-exposure stormwater schemes: A critical review of regulatory frameworks and path forward. Sustain Cities Soc 28:453-465

Booth DB (1991) Urbanization and the natural drainage system - impacts, solutions, and prognoses. Northwest Environ J 7(1):93-118
Brown HL, Bos DG, Walsh CJ, Fletcher TD, RossRakesh S (2016) More than money: How multiple factors influence householder participation in at-source stormwater management. J Environ Plan Manag 59(1):79-97. https://doi.org/10.1080/09640568. 2014.984017

Brown S (2013) Square peg in a round hole: Are flow-based TMDLs the wrong approach to manage stormwater runoff? Water Law Policy Monit 6:1-8

Brown S (2018) Storm survey: Water Environment Federation survey on MS4 communities highlights funding need. Water Wastes Dig 57(10):8-8

Burcher CL, Valett HM, Benfield EF (2007) The land-cover cascade: Relationships coupling land and water. Ecology 88(1):228-242. https://doi.org/10.1890/00129658(2007)88[228:tlcrcl]2.0.co;2

Cappiella K, Stack WP, Fraley-McNeal L, Lane C, McMahon G (2012) Strategies for managing the effects of urban development on streams. United States Geological Survey Circular 1378:80

Carle MV, Halpin PN, Stow CA (2005) Patterns of watershed urbanization and impacts on water quality. J Am Water Resour Assoc 41(3):693708. https://doi.org/10.1111/j.1752-1688.2005.tb03764.x

Carpenter SR, Caraco NF, Correll DL, Howarth RW, Sharpley AN, Smith VH (1998) Nonpoint pollution of surface waters with phosphorus and nitrogen. Ecol Appl 8(3):559-568. https://doi. org/10.1890/1051-0761(1998)008[0559:nposww]2.0.co;2

Cartwright LA, Cvetkovic M, Graham S, Tozer D, Chow-Fraser P (2015) URBAN: Development of a citizen science biomonitoring program based in Hamilton, Ontario, Canada. Int J Sci Educ Part B-Commun Pub Engage 5(2):93-113. https://doi.org/10. 1080/21548455.2013.855353

Center for Disaster Resilience (2018) The growing threat of urban flooding: A national challenge. https://cdr.umd.edu/sites/cdr. umd.edu/files/resource_documents/urban-flooding-report-vol2-online.pdf. Accessed 15 Apr 2020

Cettner A, Ashley R, Viklander M, Nilsson K (2013) Stormwater management and urban planning: Lessons from 40 years of innovation. J Environ Plan Manag 56(6):786-801. https://doi.org/10.1080/ 09640568.2012.706216

Chaffin BC, Shuster WD, Garmestani AS, Furio B, Albro SL, Gardiner $M$ et al (2016) A tale of two rain gardens: Barriers and bridges to adaptive management of urban stormwater in Cleveland, Ohio. J Environ Manage 183:431-441. https://doi.org/10.1016/j.jenvman. 2016.06.025

Chesapeake Bay Foundation (2019) Pushing forward: 2019 annual report. https://www.cbf.org/document-library/financialdocuments/2019-annual-report-no-lists.pdf. Accessed 15 Jun 2020

Chini CM, Canning JF, Schreiber KL, Peschel JM, Stillwell AS (2017) The Green Experiment: Cities, green stormwater infrastructure, and sustainability. Sustainability 9:105

Civian F (2018) Stormwater in the 21st century: How the 2016 MS4 permit will transform municipal stormwater management in Massachusetts. NEWEA J Fall 2018:54-56

Coleman S, Hurley S, Rizzo D, Koliba C, Zia A (2018) From household to watershed: A cross-scale analysis of residential intention to adopt green stormwater infrastructure. Landsc Urban Plan 180:195-206

Collins KA, Lawrence TJ, Stander EK, Jontos RJ, Kaushal SS, Newcomer TA et al (2010) Opportunities and challenges for managing nitrogen in urban stormwater: A review and synthesis. Ecol Eng 36(11):1507-1519. https://doi.org/10.1016/j.ecoleng. 2010.03.015

Cook EA (2007) Green site design: Strategies for storm water management. J Green Build 2(4):46-56. https://doi.org/10.3992/ jgb.2.4.46

Darnthamrongkul W, Mozingo LA (2020) Challenging anthropocentric stormwater management: Advancing legislation for environmental sustainability in the United States. Water Secur 10:100064 
Dhakal KP, Chevalier LR (2016) Urban stormwater governance: The need for a paradigm shift. Environ Manage 57(5):1112-1124. https://doi.org/10.1007/s00267-016-0667-5

Dhakal KP, Chevalier LR (2017) Managing urban stormwater for urban sustainability: Barriers and policy solutions for green infrastructure application. J Environ Manage 203:171-181

Dong X, Guo H, Zeng S (2017) Enhancing future resilience in urban drainage system: Green vs. grey infrastructure. Water Res 124:280-289

Drevno A (2018) From fragmented to joint responsibilities: Barriers and opportunities for adaptive water quality governance in California's urban-agricultural interface. Resources 7:22

Eisen JB (1995) Toward a sustainable urbanism: Lessons from federal regulation of urban stormwater runoff. Wash J Urban Contemporary Law 48:1-86

Eitzmann JL, Paukert CP (2010) Urbanization in a Great Plains river: Effect on fishes and food webs. River Res Appl 26(8):948-959. https://doi.org/10.1002/rra.1326

Elmqvist T, Setala H, Handel SN, van der Ploeg S, Aronson J, Blignaut JN et al (2015) Benefits of restoring ecosystem services in urban areas. Curr Opin Environ Sustain 14:101-108. https://doi.org/10.1016/j.cosust.2015.05.001

Eriksson E, Baun A, Scholes L, Ledin A, Ahlman S, Revitt M et al (2007) Selected stormwater priority pollutants - a European perspective. Sci Total Environ 383(1-3):41-51. https://doi.org/ 10.1016/j.scitotenv.2007.05.028

Fanelli R, Prestegaard K, Palmer M (2017) Evaluation of infiltrationbased stormwater management to restore hydrological processes in urban headwater streams. Hydrol Process 31(19):3306-3319. https://doi.org/10.1002/hyp.11266

Fedorchak A, Dymond R, Campbell W (2017) The financial impact of different stormwater fee types: A case study of two municipalities in Virginia. J Am Water Resourc Assoc 53:1583-1584

Fitzpatrick FA, Peppler MC (2010) Relation of urbanization to stream habitat and geomorphic characteristics in nine metropolitan areas of the United States. United States Geological Survey Scientific Investigations Report 2010-5056. pp 41

Fletcher TD, Andrieu H, Hamel P (2013) Understanding, management and modelling of urban hydrology and its consequences for receiving waters: A state of the art. Adv Water Resour 51:261-279. https://doi.org/10.1016/j.advwatres.2012.09.001

Giese E, Rockler A, Shirmohammadi A, Pavao-Zuckerman MA (2019) Assessing watershed-scale stormwater green infrastructure response to climate change in Clarksburg. Maryland J Water Resour Plan Manag 145(10):05019015. https://doi.org/ 10.1061/(asce)wr.1943-5452.0001099

Goonetilleke A, Thomas E, Ginn S, Gilbert D (2005) Understanding the role of land use in urban stormwater quality management. J Environ Manage 74(1):31-42

Hale RL (2016) Spatial and temporal variation in local stormwater infrastructure use and stormwater management paradigms over the 20th Century. Water 8(7):310. https://doi.org/10.3390/ w8070310

Harris CR (2018) Green infrastructure for Chesapeake stormwater management in a changing climate. Environ Law Report News Anal 48:10150-10172

Hawley RJ (2018) Making stream restoration more sustainable: A geomorphically, ecologically, and socioeconomically principled approach to bridge the practice with the science. Bioscience 68(7):517-528. https://doi.org/10.1093/biosci/biy048

Hawley RJ, Goodrich JA, Korth NL, Rust CJ, Fet EV, Frye C et al (2017) Detention outlet retrofit improves the functionality of existing detention basins by reducing erosive flows in receiving channels. J Am Water Resour Assoc 53(5):1032-1047. https:// doi.org/10.1111/1752-1688.12548
Hawley RJ, Lyons J, Wolnitzek G, Lodor ML (2015) Stream daylighting - a viable CSO mitigation strategy. World Water: Stormwater Manage 3:17-19

Hawley RJ, MacMannis KR, Wooten MS, Fet EV, Korth NL (2020) Suburban stream erosion rates in northern Kentucky exceed reference channels by an order of magnitude and follow predictable trajectories of channel evolution. Geomorphology 352:106998. https://doi.org/10.1016/j.geomorph.2019.106998

Hawley RJ, Wooten MS, MacMannis KR, Fet EV (2016) When do macroinvertebrate communities of reference streams resemble urban streams? The biological relevance of Q(critical). Freshw Sci 35(3):778-794. https://doi.org/10.1086/687808

Heasley EL, Millington JDA, Clifford NJ, Chadwick MA (2020) A waterbody typology derived from catchment controls using self-organising maps. Water 12(1):78. https://doi.org/10.3390/w12010078

Hilliges R, Schriewer A, Helmreich B (2013) A three-stage treatment system for highly polluted urban runoff. J Environ Manage 128:306-312

Hoard CJ, Haefner RJ, Shuster WD, Pieschek RL, Beeler S (2020) Full water-cycle monitoring in an urban catchment reveals unexpected water transfers (Detroit MI, USA). J Am Water Resour Assoc 56(1):82-99. https://doi.org/10.1111/1752-1688.12814

Hobbie SE, Finlay JC, Janke BD, Nidzgorski DA, Millet DB, Baker LA (2017) Contrasting nitrogen and phosphorus budgets in urban watersheds and implications for managing urban water pollution. Proc Natl Acad Sci USA 114(16):4177-4182. https://doi.org/10. 1073/pnas.1618536114

Hoover F-A, Hopton ME (2019) Developing a framework for stormwater management: Leveraging ancillary benefits from urban greenspace. Urban Ecosyst 22(6):1139-1148. https://doi.org/ 10.1007/s11252-019-00890-6

Hopkins KG, Bhaskar AS, Woznicki SA, Fanelli RM (2020) Changes in event-based streamflow magnitude and timing after suburban development with infiltration-based stormwater management. Hydrol Process 34(2):387-403. https://doi.org/10.1002/hyp. 13593

Irvine K, Rossi MC, Vermette S, Bakert J, Kleinfelder K (2011) Illicit discharge detection and elimination: Low-cost options for source identification and trackdown in stormwater systems. Urban Water J 8(6):379-395

Jarden KM, Jefferson AJ, Grieser JM (2016) Assessing the effects of catchment-scale urban green infrastructure retrofits on hydrograph characteristics. Hydrol Process 30(10):1536-1550. https:// doi.org/10.1002/hyp.10736

Jefferson AJ, Bhaskar AS, Hopkins KG, Fanelli R, Avellaneda PM, McMillan SK (2017) Stormwater management network effectiveness and implications for urban watershed function: A critical review. Hydrol Process 31(23):4056-4080. https://doi.org/10. 1002/hyp.11347

Kautza A, Sullivan SMP (2015) Shifts in reciprocal river-riparian arthropod fluxes along an urban-rural landscape gradient. Freshw Biol 60(10):2156-2168. https://doi.org/10.1111/fwb.12642

Kautza A, Sullivan SMP (2016) Anthropogenic and natural determinants of fish food-chain length in a midsize river system. Freshw Sci 35(3):895-908. https://doi.org/10.1086/685932

Kea K, Dymond R, Campbell W (2016) An analysis of patterns and trends in United States stormwater utility systems. J Am Water Resour Assoc 53(6): 1433-1449

Keeley M, Koburger A, Dolowitz DP, Medearis D, Nickel D, Shuster W (2013) Perspectives on the use of green infrastructure for stormwater management in Cleveland and Milwaukee. Environ Manage 51(6):1093-1108. https://doi.org/10.1007/s00267-013-0032-x

Kielstra BW, Chau J, Richardson JS (2019) Measuring function and structure of urban headwater streams with citizen scientists. Ecosphere 10(4):e02720. https://doi.org/10.1002/ecs2.2720 
Kim HW, Li M-H (2017) Managing stormwater for urban sustainability: An evaluation of local comprehensive plans in the Chesapeake Bay watershed region. J Environ Plan Manage 60(10):1702-1725. https://doi.org/10.1080/09640568.2016.1251399

Levin R, Solomon J, Agyapong C (2011) Some causes of municipal distress and bankruptcy. https://www.nabl.org/portals/0/docum ents/panel_21_-_levin_material.pdf. Accessed 5 May 2020

Liu J, Sample DJ, Bell C, Guan Y (2014) Review and research needs of bioretention used for the treatment of urban stormwater. Water 6(4):1069-1099. https://doi.org/10.3390/w6041069

Loperfido JV, Noe GB, Jarnagin ST, Hogan DM (2014) Effects of distributed and centralized stormwater best management practices and land cover on urban stream hydrology at the catchment scale. J Hydrology 519:2584-2595. https://doi.org/10.1016/j.jhydrol. 2014.07.007

Malinowski PA, Wu JS, Pulugurtha S, Stillwell AS (2018) Green infrastructure retrofits with impervious area reduction by property type: Potential improvements to urban stream quality. J Sustain Water Built Environ 4(4):04018012. https://doi.org/10.1061/ jswbay.0000866

Manocha N, Babovic V (2017) Development and valuation of adaptation pathways for storm water management infrastructure. Environ Sci Policy 77:86-97

Matejicev L, Benesova L, Tonika J (2003) Ecological modelling of nitrate pollution in small river basins by spreadsheets and GIS. Ecol Modell 170(2-3):245-263. https://doi.org/10.1016/s03043800(03)00232-1

Mayer AL, Shuster WD, Beaulieu JJ, Hopton ME, Rhea LK, Roy AH et al (2012) Building green infrastructure via citizen participation: A six-year study in the Shepherd Creek (Ohio). Environ Practi 14(1):57-67. https://doi.org/10.1017/s1466046611000494

Mazzotta MJ, Besedin E, Speers AE (2014) A meta-analysis of Hedonic studies to assess the property value effects of Low Impact Development. Resources 3(1):31-61

McKenzie B (2021) Green infrastructure: Strengthening federal policy for flood mitigation, ecosystems, and community well-being. Colorado Nat Resour Energy Environ Law Rev 32:109-134

Meng TD, Hsu D (2019) Stated preferences for smart green infrastructure in stormwater management. Landsc Urban Plan 187:1-10

Meyer JL, Paul MJ, Taulbee WK (2005) Stream ecosystem function in urbanizing landscapes. J N Am Benthol Soc 24(3):602-612. https://doi.org/10.1899/04-021.1

Miller SM, Montalto FA (2019) Stakeholder perceptions of the ecosystem services provided by green infrastructure in New York City. Ecosyst Serv 37:100928

Milwaukee Metropolitan Sewerage District (MMSD) (2018) Using green infrastructure to enhance urban biodiversity in the MMSD Planning Area. https://www.mmsd.com/application/files/3415/ 5362/4088/MMSD_Urban_Biodiversity_Plan.pdf. Accessed 5 Oct 2020

Montalto F, Behr C, Alfredo K, Wolf M, Arye M, Walsh M (2007) Rapid assessment of the cost-effectiveness of low impact development for CSO control. Landsc Urban Plan 82:117-131

Murphy BM, Russell KL, Stillwell CC, Hawley R, Scoggins M, Hopkins KG, Burns MJ, Taniguchi-Quan KT, Macneale KH, Smith RF (2021) Closing the gap on wicked urban steam restoration problems: integrating science and social-ecological values. Freshw Sci

Napieralski JA, Carvalhaes T (2016) Urban stream deserts: Mapping a legacy of urbanization in the United States. Appl Geogr 67:129-139. https://doi.org/10.1016/j.apgeog.2015. 12.008

National Association of Clean Water Agencies (2018) MS4 Stormwater Permitting Guide. https://www.nacwa.org/docs/default-source/ news-publications/white-papers/2018-03-07permittingguide.pdf? sfvrsn=29e1f761_4. Accessed 12 Apr 2020
National Research Council (NRC) (2009) Urban stormwater management in the United States. The National Academies Press, Washington, DC, p 610

Natural Resources Conservation Service (NRCS) (2020a) Environmental Quality Incentives Program. https://www.nrcs.usda. gov/wps/portal/nrcs/main/national/programs/financial/eqip/. Accessed 1 Aug 2021

Natural Resources Conservation Service (NRCS) (2020b) Water. https://www.nrcs.usda.gov/wps/portal/nrcs/main/national/ water/. Accessed 2 Jul 2020

Nemes V, La Nauze A, Walsh CJ, Fletcher TD, Bos DG, RossRakesh $S$ et al (2016) Saving a creek one bid at a time: A uniform price auction for urban stormwater retention. Urban Water J 13(3):232-241. https://doi.org/10.1080/1573062x.2014. 988732

Neukrug HM, Camp D (2009) A triple bottom line assessment of traditional and green infrastructure options for controlling CSO events in Philadelphia's watersheds: Final Report. Boulder, Colorado, USA: Stratus Consulting, Inc.

Novotny V, Ahern J, Brown PR (2010) Water centric sustainable communities: planning, retrofitting, and building the next urban environment. Wiley, Hoboken, NJ, USA

NRDC v. Costle (1977) 568 F.2d 1369. United States Court of Appeals for the District of Columbia Circuit

O'Driscoll M, Clinton S, Jefferson A, Manda A, McMillan S (2010) Urbanization effects on watershed hydrology and in-stream processes in the Southern United States. Water 2(3):605-648. https://doi.org/10.3390/w2030605

Odefey J, Detwiler S, Rousseau K, Trice A, Blackwell R, O’Hara K et al (2012) Banking on green: A look at how green infrastructure can save municipalities money and provide economic benefits community-wide. Joint Report by American Rivers, the Water Environment Federation, the American Society of Landscape Architects and ECONorthwest, $\mathrm{p} 44$

Palmer MA, Bernhardt ES, Allan JD, Lake PS, Alexander G, Brooks $S$ et al (2005) Standards for ecologically successful river restoration. J Appl Ecol 42(2):208-217. https://doi.org/10.1111/j. 1365-2664.2005.01004.x

Parkinson J (2003) Drainage and stormwater management strategies for low-income urban communities. Environ Urban 15(2):115-126. https://doi.org/10.1177/095624780301500203

Paul MJ, Meyer JL (2001) Streams in the urban landscape. Annu Rev Ecol Syst 32:333-365. https://doi.org/10.1146/annurev.ecolsys. 32.081501 .114040

Pizzuto JE, Hession WC, McBride M (2000) Comparing gravel-bed rivers in paired urban and rural catchments of southeastern Pennsylvania. Geology 28(1):79-82. https://doi.org/10.1130/00917613(2000)028\%3c0079:cgripu\%3e2.0.co;2

Porse E, Pincetl S (2019) Effects of stormwater capture and use on urban streamflows. Water Resour Manag 33(2):713-723. https:// doi.org/10.1007/s11269-018-2134-y

Pries A (2019) Mountain Creek near deal on \$28M sewer debt, ending bankruptcy. https://www.nj.com/sussex-county/2018/11/mountain_creeks_ potential_new_owner_is_a_vernon_na.html. Accessed 20 Mar 2020

Prosser T, Morison PJ, Coleman RA (2015) Integrating stormwater management to restore a stream: Perspectives from a waterway management authority. Freshw Sci 34(3):1186-1194. https://doi. org/10.1086/682566

Pennsylvania Department of Environmental Protection (2021a) Agricultural Plan Reimbursement Program 2017-2021. https://www.dep.pa. gov/Business/Water/Pennsylvania\%E2\%80\%99s\%20Chesapeake\% 20Bay\%20Program\%20Office/agriculture/Pages/Funding-Programs. aspx. Accessed 1 Aug 2021

Pennsylvania Department of Environmental Protection (2021b) Growing Greener Plus Grants Program. https://www.dep.pa.gov/Citizens/ 
GrantsLoansRebates/Growing-Greener/Pages/default.aspx. Accessed 1 Aug 2021

Ramsey MM, Munoz-Erickson TA, Melendez-Ackerman E, Nutch CJ, Branoff BL, Carrasquillo-Medrano D (2019) Overcoming barriers to knowledge integration for urban resilience: A knowledge systems analysis of two flood-prone communities in San Juan, Puerto Rico. Environ Sci Policy 99:48-57

Read LK, Hogue TS, Edgley R, Mika K, Golds M (2019) Evaluating the impacts of stormwater management on streamflow regimes in the Los Angeles River. J Water Resour Plan Manag 145(10):05019016. https://doi.org/10.1061/(asce)wr.1943-5452. 0001092

Roy AH, Rhea LK, Mayer AL, Shuster WD, Beaulieu JJ, Hopton ME et al (2014) How much is enough? Minimal responses of water quality and stream biota to partial retrofit stormwater management in a suburban neighborhood. PLoS One 9(1):e85011. https://doi.org/10.1371/journal.pone.0085011

Roy AH, Wenger SJ, Fletcher TD, Walsh CJ, Ladson AR, Shuster WD et al (2008) Impediments and solutions to sustainable, watershedscale urban stormwater management: Lessons from Australia and the United States. Environ Manage 42(2):344-359. https://doi. org/10.1007/s00267-008-9119-1

Schroeder BJ (2015) Clean Water Act basics for farmers. https://www. aglaw.us/schroeder-ag-law-blog/2015/9/26/clean-water-actbasics-for-farmers. Accessed 26 Sept 2015

Schroer H (2020) When going green means going into the red: Pennsylvania's struggle funding stormwater regulations creates water woes for MS4s. Villanova Law Rev 65(1):223-258

Shandas V, Matsler AM, Caughman L, Harris A (2020) Towards the implementation of green stormwater infrastructure: Perspectives from municipal managers in the Pacific Northwest. J Environ Plan Manag 63(6):959-980. https://doi.org/10.1080/09640568. 2019.1620708

Shupe SM (2017) High resolution stream water quality assessment in the Vancouver, British Columbia region: A citizen science study. Sci Total Environ 603:745-759. https://doi.org/10.1016/j. scitotenv.2017.02.195

Shuster W, Rhea L (2013) Catchment-scale hydrologic implications of parcel-level stormwater management (Ohio USA). J Hydrol 485:177-187. https://doi.org/10.1016/j.jhydrol.2012.10.043

Simon A, Klimetz L (2008) Relative magnitudes and sources of sediment in benchmark watersheds of the Conservation Effects Assessment Project. J Soil Water Conserv 63(6):504-522. https:// doi.org/10.2489/jswc.63.6.504

Smith RF, Hawley RJ, Neale MW, Vietz GJ, Diaz-Pascacio E, Herrmann J et al (2016) Urban stream renovation: Incorporating societal objectives to achieve ecological improvements. Freshw Sci 35(1):364-379. https://doi.org/10.1086/685096

Sparkman SA, Hogan DM, Hopkins KG, Loperfido JV (2017) Modeling watershed-scale impacts of stormwater management with traditional versus Low Impact Development design. J Am Water Resour Assoc 53(5):1081-1094. https://doi.org/10.1111/1752-1688.12559

Subramanian R (2016) Rained out: Problems and solutions for managing urban stormwater runoff. Ecol Law Q 43(2):421-448

Taylor AC, Fletcher TD (2006) Triple-bottom-line assessment of urban stormwater projects. Water Sci Technol 54:459-466

Tetra Tech Inc (2006) Assessment report on Tetra Tech's support of California's MS4 stormwater program. https://www3.epa.gov/ region9/water/npdes/pdf/ms4/ca/tetra-tech-ms4-stormwaterreport.pdf. Accessed 17 May 2020

Thurston HW, Goddard HC, Sziag D, Lemberg B (2003) Controlling storm-water runoff with tradable allowances for impervious surfaces. J Water Res Plan Manag 129:409-418

Turner VK, Jarden K, Jefferson A (2016) Resident perspectives on green infrastructure in an experimental suburban stormwater management plan. Cities and the Environment (CATE) 9(1):4
United Nations Department of Economic and Social Affairs (2019) World urbanization prospects: The 2018 revision. https:// population.un.org/wup/Publications/Files/WUP2018-Report. pdf. Accessed 10 Feb 2020

United States Census Bureau (2019) TIGER/Line Shapefiles. https:// www.census.gov/geographies/mapping-files/time-series/geo/tigerline-file.html. Accessed 20 Aug 2020

United States Census Bureau (2020) Urban and Rural. https://www. census.gov/programs-surveys/geography/guidance/geo-areas/ urban-rural.html. Accessed 20 Oct 2020

United States Environmental Protection Agency (USEPA) (2005) Fact Sheet 2.0 - an overview of the small MS4 stormwater program EPA 833-F-00-002. https://www3.epa.gov/npdes/pubs/ fact2-0.pdf. Accessed 21 May 2020

United States Environmental Protection Agency (USEPA) (2010) Stormwater Discharges from Municipal Sources. https://www. epa.gov/npdes/stormwater-discharges-municipal-sources. Accessed 20 May 2020

United States Environmental Protection Agency (USEPA) (2012) Stormwater Phase II Final Rule Who's Covered? Designation and Waivers of Regulated Small MS4s (Fact Sheet 2.1). Document No. EPA 833-F-00-003. https://www3.epa.gov/npdes/ pubs/fact2-1.pdf. Accessed 25 Jun 2020

United States Environmental Protection Agency (USEPA) (2020) Stormwater Runoff. https://www3.epa.gov/region9/water/ npdes/stormwater-feature.html. Accessed 5 May 2020

University of North Carolina School of Government (2020) Environmental Finance Center. https://efc.sog.unc.edu/. Accessed 25 Oct 2020

US Water Alliance (2020) One Water Hub. http://uswateralliance.org/ one-water. Accessed 25 Oct 2020

Vietz GJ, Sammonds MJ, Walsh CJ, Fletcher TD, Rutherfurd ID, Stewardson MJ (2014) Ecologically relevant geomorphic attributes of streams are impaired by even low levels of watershed effective imperviousness. Geomorphology 206:67-78. https://doi.org/10.1016/j.geomorph.2013.09.019

Vineyard D, Ingwersen WW, Hawkins TR, Xue XB, Demeke B, Shuster W (2015) Comparing green and grey infrastructure using life cycle cost and environmental impact: A rain garden case study in Cincinnati. OH J Am Water Resour Assoc 51(5):1342-1360. https://doi.org/10.1111/1752-1688.12320

Walsh CJ, Booth DB, Burns MJ, Fletcher TD, Hale RL, Hoang LN et al (2016) Principles for urban stormwater management to protect stream ecosystems. Freshw Sci 35(1):398-411. https:// doi.org/10.1086/685284

Walsh CJ, Roy AH, Feminella JW, Cottingham PD, Groffman PM, Morgan RP (2005) The urban stream syndrome: Current knowledge and the search for a cure. J N Am Benthol Soc 24(3):706-723. https://doi.org/10.1899/04-028.1

Walsh MJ (2012) In Alabama, a county that fell off the financial cliff. https://www.nytimes.com/2012/02/19/business/ jefferson-county-ala-falls-off-the-bankruptcy-cliff.html. Accessed 11 Jun 2020

Ward B, MacMullan E, Reich S (2008) The effect of low impact development on property values. http://www.12000raingardens. org/wp-content/uploads/2013/03/The-Effect-of-Low-IncomeDevelopment-on-Property-Values.pdf. Accessed 11 Jun 2020

Wenger SJ, Roy AH, Jackson CR, Bernhardt ES, Carter TL, Filoso S et al (2009) Twenty-six key research questions in urban stream ecology: An assessment of the state of the science. J N Am Benthol Soc 28(4):1080-1098. https://doi.org/10.1899/08-186.1

William R, Endres AB, Stillwell AS (2020) Integrating green infrastructure into stormwater policy: Reliability, watershed management, and environmental psychology as holistic tools for success. UCLA J Environ Law Policy 38:37-60 
William R, Garg J, Stillwell AS (2017) A game theory analysis of green infrastructure stormwater management policies. Water Resour Res 53:8003-8019

Willis GJ, McDowell LL (1982) Pesticides in agricultural runoff and their effects on downstream water quality. Environ Toxicol Chem 1(4):267-279

Wohl E, Merritts DJ (2007) What is a natural river? Geogr Compass 1(4):871-900
Woznicki SA, Hondula KL, Jarnagin ST (2018) Effectiveness of landscape-based green infrastructure for stormwater management in suburban catchments. Hydrol Process 32(15):2346-2361. https://doi.org/10.1002/hyp.1314

Zhang H, Ahmad Z, Shao Y, Yang Z, Jia Y, Zhong H (2021) Bioretention for removal of nitrogen: Processes, operational conditions, and strategies for improvement. Environ Sci Pollut R 28:10519-10535 